\title{
Nigerian Democracy and Electoral Process since Amalgamation: Lessons from a Turbulent Past*.
}

\author{
Dr Abiodun Odusote
}

\begin{abstract}
Nigerian democratic process has endured a cheaqured history is irrefutable, as research has shown, Nigerian political and electoral process is characterized by banditry, rigging, ballot stuffing, candidate imposition and other vices. This research highlights factors that are responsible for this state of affairs. It examines the inextricable link between democracy, good governance, political and electoral process and argues that they have impact on national stability and development. It addresses factors inhibiting the political and electoral process from amalgamation till date. It identifies and explores the broad consequences of continued circumventions of the electoral system by the political elites. In the light of present and enduring interest in the role of a credible political and electoral system, it is argues that an assessment is needed of the potential for change in existing arrangements. This research reveals that democracy, political and electoral processes must be sensitive to the heterogeneity and variations of interest in Nigeria. The paper concludes by making recommendations and proposals.
\end{abstract}

\section{Introduction}

Democracy is underpinned by three essential components: healthy competition among political parties, political participation by the populace in electing their leaders, and a credible electoral process. In a democracy, power and significant decisions in a society is distributed among the population which is carried out by the elected representatives of the people. Viable political parties and credible elections are essential components of a democracy. Electoral systems in civilised societies permit the co-existence of different units, tribes, nations and diverse schools of political ideologies and religious beliefs to live in peace and harmony by surrendering their rights to the people they have elected to govern and manage their resources for a given period of time.

An effective democracy and electoral system is founded upon the ability to hold free and fair elections, independent and effective electoral umpire, effective policing, and incorruptible and responsive judiciary. This paper sadly notes that since independence, Nigeria has experienced a "horrific cycle of corrupt, inept and despotic civilian and pseudo-civilian rules"1. The reason is not far-fetched. The Nigerian political leadership came to power through flawed electoral systems that are always marred by poor organisation, lack of transparency, widespread procedural irregularities, and significant evidence of fraud, banditry, and unequal playing field. Other vices commonly experienced in the Nigerian electoral process include unjust disqualification of candidates, stealing of data capturing machines, politically bias police and until recently a biased umpire, INEC.

This paper begins with a brief introduction and highlight of the general features of the Nigerian democracy since amalgamation, political process and electoral process. In part two, the focus of the paper is on conceptual clarifications to give context to various terminologies that are engaged in the paper. Part three interrogates the Nigerian democracy and political systems from amalgamation to contemporary times. The paper gives a summary account of Nigerian's constitutional and democratic development, this discourse, and lessons learnt from the various flawed general elections underpin the recommendations in the concluding part. The study engages the electoral process in part four, while part five, concludes the discourse.

\section{Clarification of Terms} process."

This part clarifies the meaning of the following terms: "democracy," "electoral process," and "political Democracy

\footnotetext{
* Dr. Abiodun Odusote is with the Public Law Department, University of Lagos, Akoka

1 O.O. Olarinmoye, "Godfathers, political parties and electoral corruption in Nigeria" African Journal of Political Science and International Relations Vol. 2 (4), pp. 066-073, December 2008 Available online at http://www.academicjournals.org/AJPSIR; Adeyemi SW (2004). "Godfatherism and Political Development: Understanding its Impact on Nigeria's Emerging Democracy", Essence, Interdisciplinary- Int. J. Philo., 1(1) : 72-80.
} 
Abraham Lincon defined democracy as government by the people and for the people. ${ }^{2}$ Zach-Wiiliams posits that democracy has to do with the ability of the people to control decision making process. ${ }^{3}$ Robert A. Dahl defines democracy as "a society in which ordinary citizens exert a relatively high degree of control over leaders" $"$.

Samuel Huntington, views democracy as a political system in which:

Its most powerful decision-makers are selected through fair, honest and periodic, elections in which candidates freely compete for votes and in which virtually all the adult population is eligible to vote ${ }^{5}$

Oyebode put the icing on the cake by asserting that democracy comes with some "appurtenancesseparation of powers, adult suffrage, and freedom of speech and of the press, equality before the law, independent judiciary, and right of dissent."

Electoral Process

Ariwoola JSC held in N.D.P $\mathrm{v} I N E C^{7}$ that electoral process is the method, "by which a person is elected to public office in a democratic society ${ }^{8 \%}$. Nwabueze observed that a credible electoral process must include:

...the suffrage, the registration of voters, delimitation of constituencies, the right to contest elections, electoral competition between rival parties, the body charged with the conduct and supervision of election, the method of electing candidates within the political parties, nomination of candidates, method of voting, the actual conduct of elections, the determination of results, trial and determination of election disputes, electoral malpractices and their consequences?

In the opinion of Boix, electoral systems... are the composite, of different rules regulating the access of citizens to suffrage, the number and use of votes by voters, the number and size of electoral districts, the introduction of thresholds and bonuses, and the allocation mechanisms used to transform votes into seats ${ }^{10}$ Crush in a comprehensive and all-embracing definition of the electoral process stated:

Electoral systems are the 'most powerful lever of political engineering for conflict resolution'... it determines how votes translate into seats in the legislature... and thereby determining many aspects of the functioning of democracy: what the parties look like, who is represented and by whom, and 'ultimately who govern' ... Therefore, the electoral system is the gateway to power in a democracy. It can be manipulated to foster accommodative behaviour by ensuring that groups are included in the political process by decreasing the incidence of zero-sum outcomes... Furthermore, by changing the incentives available to those seeking election, electoral rules can make some types of behaviour more politically rewarding than others, making it possible to incentivise inclusiveness and moderation...Thus, the electoral system is fundamental to the political culture in a society... While getting this right is only one part of the quest for stability, getting it wrong can make stability impossible. ${ }^{11}$

We agree with all the scholars above in their robust and diverse perception of democracy, political process, and electoral process. The terminologies accommodate diverse views and prejudices. The common denominator is that a democratic rule is a government by the people of their chosen and freely elected representative. It is a government based on the rule of law, free and fair elections, and credible electoral process. There is an obvious matrix between democracy and electoral process. If there is no credible election, there cannot be a credible democracy. Democracy is anchored on a credible electoral system because if there are no elections, there cannot be political office holders that will exercise the peoples' sovereignty. When politicians rig elections to get into public offices they truncate the wish of the people. Hence, public office holders wear the garment of impunity and treat the people with brazen disdain and contempt because they are not accountable to

\footnotetext{
${ }^{2}$ He was the President of the U.S. between 1861-65. He made the statement as part of his Gettysburg Address on Thursday November 19, 1963.

${ }^{3}$ Zach-Wiiliams A B, “No Democracy, No Development: Reflections of Democracy and Development in Africa” Review of African Political Economy Vol. 28, pp213-223

${ }^{4}$ Robert A. Dahl, A reference to Democratic Theory, (Chicago, 1956)

${ }^{5}$ Adejumobi Said, "Traditional Rulers and the Democratisation Process in Nigeria: 1985-1995. Being a paper presented to the Conference on Democratisation and Corruption in Nigeria organized by Prof. Alex Gboyega, University of Ibadn in conjuction with Friedreich Ebert Foundation, September 1995, University of Ibadan

${ }^{6}$ Oyebode, "Constitutional Reform and the Future of Democracy in Nigeria" http://www.nigeriavillagesquare.com

7 (2013) 20 WRN 1

${ }^{8}$ Ibid PP 25-26

9 O. Sanusi, Election Administration in Nigeria: A Comparative Analysis with the United States of America' cdra.org.ng/home/?page_id=131

${ }^{10}$ Carles Boix, 'Setting the Rules of the Game: The Choice of Electoral Systems in Advanced Democracies', American Political Science Review, Vol. 93, No. 3 (September, 1999) pp. 609-624

${ }^{11}$ J Crush, 'Electoral Systems and Stability in Divided Societies,' e-international relations, http://www.e-ir.info/2013/05/10/electoralsystems-and-stability-in-divided-societies.
} 
Nigerian Democracy and Electoral Process since Amalgamation: Lessons from a Turbulent Past*.

the people. Votes do not count. On the other hand, a credible electoral system presents a responsive, transparent and accountable government, because the votes of the electorates count. Failure of the elected public office holder to be responsive and transparent will be visited during the elections.

\section{Perspectives on the Nigerian Political Systems and Democracy}

There cannot be a meaningful democracy without a proper functioning political party system ${ }^{12}$. Political parties are saddled with the responsibility of recruiting, nurturing and sponsoring competent individuals for political leadership. A political party is an organised group of individuals who share similar political beliefs, opinions, principles, aspirations, and interests with the aim of capturing political power. However, Nigerian political parties do not meet the ideals of a proper political system. The political parties in Nigeria have failed to adhere to the basic tenets of democracy and constitutionalism. They are non-ideological organisations, having less interest in political principles ${ }^{13}$. From the colonial era up till now, Nigerian political parties are weaved around primitive interests like, ethnicity, religion, and zoning. Hence, cross-carpeting is rampant and might be induced by monetary gains or promise of political appointments. This segment will now consider the evolution of political parties, problems and prospects.

\section{Pre-Independence Democracy and Electoral Process ${ }^{14}$}

Lord Luggard amalgamated the Northern and Southern Protectorates on 01 January, 1914. Just over a century ago. Nigeria gained independence on 01 October 1960. However, prior to independence, Nigeria had experimented with not less than five Constitutions: Sir Hugh Clifford Constitution of $1922^{15}$, Sir Arthur Richards Constitution of $1946^{16}$, Sir John McPherson Constitution of $1951^{17}$, and the Sir Oliver Lyttleton Constitution of $1954^{18}$

\section{Post-Independence Democracy and Electoral Process \\ (a) 1960-1966} government.

At independence, Nigeria took control of its sovereignty and adopted a federal parliamentary system of

General elections were conducted on 12 December, 1959 into local councils, Regional and Federal Legislature. Voting was by secret ballot. All registered adults in Western, and Eastern Nigeria were eligible to vote. In Northern Nigeria, only registered adult males were eligible to vote. Three regional and ethnic based parties emerged as the dominant parties, Northern People's Congress (NPC) $)^{19}$, Action Group (AG) $)^{20}$, and the National Council of Nigeria and Cameroons $(\mathrm{NCNC})^{21}$

Some unsavoury events occurred in the political arena. In the West, there was a crisis in 1962. There was a political imbroglio in the Western Region. The Governor of the Western Region had dismissed the Premier because it appeared to the Governor that the premier no longer commanded majority in the House. There was a stalemate in the region that resulted in the declaration of a State of Emergency in the region by the

\footnotetext{
${ }^{12}$ At the moment, the conditions precedents to registration of political parties are set out in Section 222 of the Constitution as follows: (a) the names and addresses of its national officers are registered with the Independent National Electoral Commission;

(b) the membership of the association is open to every citizen of Nigeria irrespective of his place of origin, circumstance of birth, sex, religion or ethnic grouping;

(c) a copy of its constitution is registered in the principal office of the Independent National Electoral Commission in such form as may be prescribed by the Independent National Electoral Commission;

(d) any alteration in its registered constitution is also registered in the principal office of the Independent National Elect oral Commission within thirty days of the making of such alteration

(e) the name of the association, its symbol or logo does not contain any ethnic or religious connotation or give the appearance that the activities of the association are confined to a part only of the geographical area of Nigeria; and

(f) the headquarters of the association is situated in the Federal Capital Territory, Abuja

Other conditions are stated in S. 78 (1) of the Electoral Act 2011 and essentially that application to be registered

${ }^{13}$ Banfield EC, Wilson JA (1965). City Politics, Cambridge, Harvard University Press ;Scott JC (1973). Comparative Political Corruption, Prentice-Hall, Inc, Englewood Cliffs, New Jersey

${ }^{14}$ This section on Pre-Independence and post-independence Democracy and Electoral Process benefitted hugely from the scholarly work of Abass, "The Nigerian Electoral Process in Perspective" and the work of Hon. Temi Harriman, "Is there a Future for Democracy in Nigeria" Being the text of a public lecture delivered at the Department of International Development, Oxford University, Uk on 05 June, 2006.

${ }^{15}$ The election only took place in Lagos and Calabar. Election was based on limited franchise and only British citizens residing in the cities and British protected persons earning a minimum gross income of 100 pounds could vote. The National Democratic Party and the Calabar Improvement League respectively won three seats in Lagos and the only seat in Calabar.

${ }^{16}$ Indirect electoral system was adopted. Regional and Central legislatures were 45 members in all, 28 members were Nigerians, 4 were elected and 24 were nominated

${ }^{17}$ General Election was by Electoral College. Greater Regional Autonomy was guaranteed.

${ }^{18}$ Electoral Collegiate system was replaced with direct elections

${ }^{19}$ Led by Ahmadu Bello

${ }^{20}$ Led by by Obafemi Awolowo

${ }^{21}$ Dr Nnamdi Azikiwe
} 
Federal Government. Also, Chief Obafemi Awolowo ${ }^{22}$, the leader of the opposition was alleged to have conspired to overthrow the federal government. He was found guilty with some prominent members of the AG and was sentenced to terms of imprisonment.

In 1963, Nigeria became a Republic, the 1963 Constitution was enacted. The Constitution embraced the rule of law, fundamental rights, and the principle of derivation.

The 1964 elections witnessed the emergence of a two-party system: The Nigerian National Alliance (NNA) and the United Progressive Grand Alliance (UPGA). This election was boycotted in the East and some other part of the country. It was characterised by intimidation, violence and arson. The NNA was called upon to form a new national broad based government.

The 1965 Western election was also characterised with increased political violence, arson, intimidation and killing of political opponents. The ruling party was alleged to have massively rigged the elections. The result announced was greeted with pandemonium and mass revolt. The Prime Minister refused to intervene in the region.

The uncertain situation resulted in the intervention of the military through coup d'etat on 15 January, 1966. The Constitution (Suspension and Modification) Decree No.1, 1966 was promulgated and the 1963 Constitution was suspended and political activities banned.

\section{(b) 1979-1983}

After 13 years of military rule, the Murtala/Obasonjo military regime lifted the ban on political parties in September 1978. The then Head of State, Gen Olusegun Obasonjo signed Decree No.25 to usher in the 1979 Constitution. The essential features of the 1979 Constitution include: the introduction of the presidential system of governance, the doctrine of separation of powers and checks and balances, there was elaborate provisions of human rights, duties and rights of citizens and independence of the judiciary. Also the executive president was both the head of government and the Commander-in-Chief of the Armed Forces.

It was the requirement of the Constitution that registered political parties must have national spread and acceptance. Five political parties ${ }^{23}$ were registered to contest the elections. However, as the elections approached, it was obvious noting really has changed as the politicians manifested ethnic, and religious sentiments. Elections outcome also confirmed that electorate pandered to ethnic-religious sentiments in their pattern of voting. $^{24}$

The presidential candidate of the National Party of Nigeria (NPN) was declared the winner of the election. The election was challenged by Chief Obafemi Awolowo, the candidate of the Unity Party of Nigeria, (UPN). The Supreme Court was called upon to interpret two-thirds of 19 states because Alhaji Shehu Shagari did not win the Constitutional requirement of 25 per cent of votes in 13 states of the Federation. The NPN contested the suit and argued that the constitutional requirement related to two-third of the votes and not the states. The issue was resolved in favour of Alhaji Shehu Shagari ${ }^{25}$ of the NPN and he was subsequently sworn in as president.

There was a huge expectation after the return of power to civilian elected government in 1979, after over a decade of military misadventure in politics. However, the democratic and electoral process collapsed as a result of grand corruption, mass looting, electoral violence and political intolerance as reflected in the Shugaba's case, where an opposing political opponent was deported from Nigeria ${ }^{26}$. It was also alleged that the 1983 elections were massively rigged by the NPN. Toyin Abe vividly captured the violence in the federal elections of 1983 when he poignantly asserted that:

During the federal elections of 1983, violence was promoted to an unimaginable level where states sponsored thugs, arsonists and assassins unrestrainedly unleashed terror and fear on both opponents and voters alike ${ }^{27}$

Overall, the country was drifting towards the brinks again. On 31 December, 1983, the military again took over the reins of government.

\footnotetext{
${ }^{22}$ Adegbenro v Akintola (1962) All NLR 462

${ }^{23}$ National Party of Nigeria (NPN), Unity Party of Nigeria (UPN), Peoples Redemption Party (PRP) Great Nigeria Peoples Party (GNPP), Nigerian Peoples Party (NPP) and in the Nigeria Advance Party was registered to contest the 1983 elections.

${ }^{24}$ The NPN was dominant in the North. The UPN was the party of choice in the South West. The NPP was popular in Anambra and Imo.

The PRP was popular in Kano and Kaduna and the GNPP reigned in Borno and Gongola States.

${ }^{25}$ Obafemi Awolowo v Shehu Shagari (1979) 6-9 S.C. 51

${ }^{26}$ Shugaba v Minister of Internal Affairs (1981) 2 NCLR 459

${ }^{27}$ Abe, T. (2008). 2007 Elections and Electoral Violence in Nigeria's Fourth Republic,

Journal of Contemporary Politics, Vol. 1. No. 1.
} 
Nigerian Democracy and Electoral Process since Amalgamation: Lessons from a Turbulent Past*.

(c) 1989-1993

The 1983 military intervention was headed by Gen. Muhammadu Buhari. The regime was reputed for fiscal discipline and the war it waged against general indiscipline in the society. However, the regime had no immediate plan to return the country to democratic rule. Gen. Ibrahim Babangida toppled the military regime of Gen. Muhammadu Buhari in August 1985.

Babangida then embarked on a seemingly endless transition to civilian rule, continuously shifting the hand over date as it suited him. Babangida inaugurated a Constitution Review Committee (CRC) to examine the 1979 Constitution and make possible recommendations. The recommendations were then incorporated into the aborted 1989 Constitution. Included in the 1989 constitutions are: provisions for a two party system, and additional fundamental rights i.e. right to free education, right to property and right to healthcare. The Constitution came into effect in phases but was aborted after the annulment of the June 12 elections by Babangida.

Prior to the elections of June 12, Babangida had created a two party system he foisted on Nigerians. He proposed that the parties will have equal founders and equal joiners (an attempt to depart from the experience of the past, where political parties revolved around individuals and ethnic alliance), which were a little to the left and $a$ little to the right (an attempt to depart from classical and parallel ideologies). The parties were named Social Democratic Party (SDP) and National Republican Party (NRC). The Babangida military government provided the Secretariat, needed fund, provided logistics and gave directions.

As we have mentioned earlier Babangida's transition was in phases, civilian governments had been installed at the local government level, at the state level, and at the National Assembly, all pandering to the selfstyled President. The presidential election was held as scheduled on June 121993 but general Babangida annulled the results. The two parties created by Babangida had contested the election which was generally agreed to have been won by the muslim-muslim candidates of the SDP; Chief M.K.O Abiola and his running mate Alhaji Babagana Kingibe. It was a golden opportunity lost. It was an election that was thought would erase religious and ethnic sentiments in Nigerian politics. The SDP enjoyed overwhelming support that cut across religious sentiments and ethnic divide. It was not to be. The election was aborted and the crisis that followed led to the famously stepping aside of Gen Babangida. Interim National Government (ING) of Ernest Shonekan was sworn in on 27 August 1993. The ING only lasted for about three months. It was swept aside by Gen. Sani Abacha on 27 November, 1993. Abacha aborted the 1989 Constitution in transition.

\section{(d) 1999-2007}

The news of Abacha's death was received with shock and bewilderment on 08 June, 1998. The military regime was immediately taken over by Gen. Abdulsalami Abubaka. The 1999 Constitution was promulgated by Abubaka's regime through Decree No.24 of May, 1999. The Constitution embraced multi-party system. However, there were three dominant parties. The three dominant parties that participated in the elections conducted by the Independent National Electoral Commission (INEC) are: Alliance for democracy (AD), All Peoples Party (APP), and the Peoples Democratic Party. Chief Olusegun Obasonjo of the PDP won the presidential elections against Chief Olu Falae of the AD-APP alliance. It should be noted that there was a general apathy to the election as the electorates had become disillusioned about democracy and were weary of the antics of the military.

In 2003, another general election was scheduled. The 2003 elections were generally regarded as landmark because it was the first time since independence that political leadership successfully changed hands from one civilian to the other. The elections were however, regarded as more fraudulent than the 1999 elections. The period preceding the elections also witnessed the assassination of two gubernatorial candidates and political banditry.

In making general assessment of the 2003 elections Awopeju observed:

US-based Carter Center concluded that "it is not possible for us to make an accurate judgement about the outcome of the presidential election" It had been tagged by the Human Rights Watch as an "abject failure." The elections were more pervasively and openly rigged than the flawed 1999 elections. ..."It is doubtful whether [...the] elections can only be considered to be reflective of the will of the people" ${ }^{28}$.

Out of the 30 registered political parties, only 20 fielded candidates for the presidential election. The election was again won by Chief Olusegun Obasonjo of the PDP. The other main contenders were, Alhaji Mohammed Buhari of the All Nigeria People's party, Chief Odumegwu Ojukwu of the All Progressive Grand Alliance and Chief Gani Fawehinmi of National Conscience Party.

\footnotetext{
${ }^{28}$ A. Awopeju, "Election Rigging And The Problems Of Electoral Act In Nigeria Afro Asian Journal of Social Sciences Volume 2, No. 2.4 Quarter IV 2011 ISSN $2229-5313$
} 
Again, the election was characterised by rigging, millions of people voted several times, in many cases election did not hold but votes were pre-filled.

The 2007 Gubernatorial and state assembly elections were held on 14 April 2007, while the Presidential and National elections were held on 21 April, 2007. Umaru Yar'Adua of the PDP won the presidential election. Main opponents were Alhaji Mohammed Buhari of the All Nigeria's Peoples Party (ANPP), and Alhaji Atiku Abubakar of the Action Congress. Atiku had earlier cross-carpeted to the Action Congress after his numerous problems with President Obasanjo and the PDP. He was accused of being fraudulent and he was caused to be disqualified by INEC. However, in Alhaji Atiku Abubakar v INEC ${ }^{29}$ the Supreme Court held that INEC does not have the power to disqualify any candidate from contesting an election, and equally lacks the capacity to remove the Vice-President from office or declare his seat vacant. The VP can only be removed by the National Assembly. The Court also held that the VP can cross-carpet without losing his seat.

The election was described by the EU Observers as the worst they had ever seen anywhere in the world. There was rampant vote rigging, violence, arson, and theft of ballot papers.

It would be recalled that President Umaru Yar'Adua died in office and President Jonathan Goodluck (the then Vice President) was sworn in as president to conclude his term in office.

On 16 April 2011, the presidential elections were held. It was won by Dr. Jonathan Goodluck of the PDP. Other main contenders were Gen. Mohammed Buhari of the Congress for Progressive Change (CPC) and Alhaji Nuhu Ribadu of the Action Congress of Nigeria (ACN). There were 17 candidates in all. The elections were heralded as among the fairest in Nigeria's history but it recorded the worst post-election violence ever in the history of Nigeria.

The aftermath of the elections witnessed the death of up to 800 people in Northern Nigeria ${ }^{30}$; among them were members of the National Youth Service Corp (NYSC) who had been engaged as INEC officials. The election manifested religious and ethnic sentiments as none before it. The majority of the southern Nigerian with predominately Christian majority voted for Dr. Jonathan Goodluck, a Christian, while the majority of the Northern Nigerian with predominantly Muslim population, voted for Alhaji Mohammed Buhari, a Muslim. It was a very disturbing electoral outcome.

\section{Challenges of Nigerian Political Systems}

Research has shown that elections are subverted by political parties and politicians in Nigeria ${ }^{31}$. This is done through the illegal use of money, deployment of thugs, intimidation, maiming and killing of opponents and perceived opponents. This subversion subsequently leads to the imposition of the preferred candidates of the godfathers. The selected candidates only pursue the narrow and selfish interest of the god fathers rather than the common good of all. Hence, the prevalence of bad governance, and inept political leadership across the country since independence. Olarinmoye argued that Nigerian political systems are characterised by the following ${ }^{32}$ : i. The emergence and evolution of Nigerian political parties are not anchored on clearly defined ideologies or ideas. They emerged through Nigerian Constitutional Development or through the evolution of the Nigerian Constitution. Nigerian political parties have no clearly articulated stand on burning issues like, unemployment, insecurity, corruption, creation of state police, payment of fees in tertiary institutions, job securities, immigration, transsexuals etc. Political parties in Nigeria hardly join issues on such important topics.

ii. Most parties have ethnic or regional bases or structured around a few individuals.

iii. At the moment only two political parties in Nigeria can boast of National spread. Contemporary history of Nigeria shows that out of all the parties that have been able to control the national government, only PDP has been able to meet the required Constitutional majority to take control without forming any alliance. In the First Republic, the NPC went into an alliance with the NCNC to form a ruling majority in the National Assembly. In the Second Republic, NPN went into alliance with the NPP to form the majority in the National Assembly. Only the PDP, having won over two thirds majority in both Houses of the National Assembly was able to form a government without any alliance.

iv. Few individuals (popularly known as godfathers) have hijacked the political parties in Nigeria. Most of the godfathers are men of questionable characters and questionable resources and pedigree.

\footnotetext{
${ }^{29}$ (2007) 6 NWLR Pt. 1029 p.142

${ }^{30}$ Human Rights Watch, "Nigeria: Post Election Violence killed 800" Available at: http://www.hrw.org/news/2011/05/16/nigeria-postelection-violence-killed-800 Accessed on 01 May, 2014

${ }^{31}$ O.O. Olarinmoye, "Godfathers, political parties and electoral corruption in Nigeria" African Journal of Political Science and International Relations Vol. 2 (4), pp. 066-073, December 2008 Available online at http://www.academicjournals.org/AJPSIR; Adeyemi SW (2004). "Godfatherism and Political Development: Understanding its Impact on Nigeria's Emerging Democracy", Essence, Interdisciplinary- Int. J. Philo., 1(1) : 72-80.

${ }^{32}$ Ibid
} 
v. Lack of intra-party democracy. All the political parties in Nigeria exhibit undemocratic dictatorial tendencies in their intra-party affairs. Oguntade JSC noted this much in the case of Ugwu \& Anor v Ararume \& Anor ${ }^{33}$ :

An observer of the Nigerian political scene today easily discovers that the failure of the parties to ensure intra-party democracy and live by the provisions of their constitutions as to the emergence of candidates for election is one of the major causes of serious problems hindering the enthronement of a representative government in this country

Political parties in Nigeria hardly conduct primaries. Candidates are either nominated by the godfathers or selected by those occupying political positions. These often result to intra-party conflicts, splitting and division. A recent example is the New PDP, which eventually 'merged' with the APC.

These features arise because party formations are based on caucus formations ${ }^{34}$. Parties are not formed based on common good or the need to address common problems, rather a few educated elites, politicians, and businessmen form caucus to finance and dominate political parties. The formation of the two leading political parties; the PDP and the APC share similar elitist history in their formations.

\section{Perspectives on the Nigerian Electoral Process}

The electoral process is the pillar of democracy because it gives effect to the right to govern by consent. Nwatu has rightly posited that "election and political choice give meaning to the right to government by consent, a requirement of legitimacy of government or state in international law" ${ }^{35}$ Given the need to have a credible election S. 153 Constitution of the Federal Republic of Nigeria (CFRN) Third Schedule Part I 14 (1) establishes the Independent National Electoral Commission and gives the body the power to:

(a) organise, undertake and supervise all elections to the offices of the President and VicePresident, the Governor and Deputy Governor of a State, and to the membership of the Senate, the House of Representatives and the House of Assembly of each State of the Federation;

(b) register political parties in accordance with the provisions of this Constitution and an Act of the National Assembly;

(c) monitor the organisation and operation of the political parties, including their finances;

(d) arrange for the annual examination and auditing of the funds and accounts of political parties, and publish a report on such examination and audit for public information;

(e) arrange and conduct the registration of persons qualified to vote and prepare, maintain and revise the register of voters for the purpose of any election under this Constitution;

(f) monitor political campaigns and provide rules and regulations which shall govern the political parties;

(g) ensure that all Electoral Commissioners, Electoral and Returning Officers take and subscribe the Oath of Office prescribed by law;

(h) delegate any of its powers to any Resident Electoral Commissioner; and

(i) carry out such other functions as may be conferred upon it by an Act of the National Assembly

The powers and functions of INEC are also guaranteed under and S. 1 and 2 of the Electoral Act 2011, which establishes and confers INEC with the electoral functions set out below: the Commission shall have power to:(a) conduct voter and civic education, (b) promote knowledge of sound democratic election processes, (c) conduct any referendum required to be conducted pursuant to the provision of the 1999 Constitution or any other law or Act of the National Assembly. INEC is required to be independent.

The 2011 Act has not only added more responsibility to INEC's Constitutional responsibilities as the electoral umpire, it also has new provisions to address recurring political problems. For example:

S. 33 provides, "a political party shall not be allowed to change or substitute its candidate whose name has been submitted pursuant to section 31 of this Act, except in the case of death or withdrawal by the candidate".

While section S. 141 provides "An election tribunal or court shall not under any circumstance declare any person a winner at an election in which such a person has not fully participated in all the stages of the said election".

These provisions are made to cure the general complaints that followed the Supreme Court decision in Amaechis's case.

\footnotetext{
33 (2007) 12 NWLR (pt.1048) 365

${ }^{34}$ Olarinmoye OO (2006) "Perverse Brokerage: Godfathers and Politics in Nigeria", The Constitution, 7 (2): 33 -43.

${ }^{35}$ Dennis-Nwatu, Electoral Process and Democracy in Nigeria
} 
Nigerian Democracy and Electoral Process since Amalgamation: Lessons from a Turbulent Past*.

In Rotimi Amaechi v INEC \& Ors ${ }^{36}$ Amaechi was initially nominated by the PDP as the party's gubernatorial candidate for Rivers state. However, following a politically motivated allegations of corruption against him (which has not be proven in a court of law), the PDP substituted his name with Omehia's name as the PDP gubernatorial candidate, in violation of S. 34 (2) of the Electoral Act. Omehia did not win the primaries. Amaechi challenged this in court. Meanwhile, while the case was still in court, the gubernatorial election was conducted and Omehia won on the platform of PDP. The SC held that the legitimate candidate for PDP was Amaechi, as his name was wrongfully removed, in the eyes of the law, Amaechi remained the PDP candidate, and must be deemed to have won. Amaechi was declared entitled to the gubernatorial seat in Rivers State and Omehia was ordered to vacate his seat

Hence, the new provisions set out above, no one can be declared a winner of any election, except he has taken part in all the electoral processes leading to the conduct of the election. It is also the law now that a political party cannot substitute or withdraw the name of a candidate, except the candidate is dead or personally withdraws from the race.

The Electoral Act also attempts to cure the infusion of dirty money into politics with the inclusion of S.14. Research has shown that candidates invest large amount of dirty money (drug money, money derived from kidnappings, proceeds of corruption) and borrowed money to contest elections, some sell their houses, while others borrow from banks and god fathers. Only individuals that are willing to spend lots of money become candidates. The amount of money spent informs the choice of candidate and largely influences who wins the elections ${ }^{37}$. The result of a research conducted among 23 out of the 27 members of the House of Assembly in Oyo, Enugu, and Kaduna states and 28 officials from different political parties indicates as follows:

1. $89 \%$ of the interviewed members of the Assembly indicated that campaign funds played a major role in securing their elections.

2. $47 \%$ of the respondents believe that money in politics helps win elections

3 . Only $47 \%$ are aware of spending limits for campaigns that are imposed by the electoral regulations. ${ }^{38}$

To arrest the influence of dirty money in politics and to prevent a situation where foreign organizations, or individuals with ulterior motives will hijack the electoral system S.91 provides:

(1) Election expenses shall not exceed the sum stipulated in subsection (2) - (7) of this section.

(2) The maximum election expenses to be incurred by a candidate at a Presidential election shall be one billion naira $(\mathrm{N} 1,000,000,000)$.

(3) The maximum election expenses to be incurred by a candidate at a Governorship election shall be two hundred million naira (N200,000,000).

(4) The maximum amount of election expenses to be incurred in respect of Senatorial seat by a candidate at an election to the National Assembly shall be forty million naira $(\mathrm{N} 40,000,000)$ while the seat for House of Representatives shall be twenty million naira $(\mathrm{N} 20,000,000)$

(5) In the case of State Assembly election, the maximum amount of election expenses to be incurred shall be ten million naira $(\mathrm{N} 10,000,000)$.

(6) In the case of a chairmanship election to an Area Council, the maximum amount of election expresses to be incurred shall be ten million naira (N10,000,000).

(7) In the case of councillorship election to an Area Council, the maximum amount of election expenses to be incurred shall be one million naira (N1,000, 000

\section{The Challenges of Nigerian Electoral Systems.}

Jega and Ibeanu, (prior to Jega becoming the Chairman of the Independent National Electoral Commission (INEC) rightly observed:

Elections in Nigeria have historically been conflict ridden. The campaigns preceding elections are invariably marked by pettiness, intolerance, and violence. Already there are several reported incidences of intra-party, as well as, inter-party violence, conflicts, including abductions and assassinations. And the elections and their outcomes have often been neither free nor fair, characterised by violations of the process (both inadvertent and wilful), corrupt conduct by officials, rigging of results and so on. Again, reports indicate that incidences of these were pervasive during the party primaries, and that some

\footnotetext{
${ }^{36}$ (2008) 5 NWLR Pt. 1080227

${ }^{37} \mathrm{IiG}$, "Campaign finance distorts Nigerian elections" available at http://www.iig.ox.ac.uk

${ }^{38}$ Ibid.
} 
candidates are busy scheming to ensure a favourable outcome for themselves, by hook or crook, in the coming elections ${ }^{39}$

\section{Edoh also observed:}

Even, under the supervisory eyes of the British, during the 1959 elections, incidents of violence, stuffing of ballot boxes as well as obstructions and intimidations of opponents were reported here and there ${ }^{40}$.

Elaigwu also looks at the trends of electoral process since 1999 when he posited that:

The electoral process has been crises-ridden since 1999. It seems each successive election since then has been worse than earlier ones. The result is that governments emerge with a baggage of crises of legitimacy, which often complicates the dynamics of federalism. This was what happened after the 2003 and 2007 elections. ${ }^{41}$

There are various factors responsible for flawed election in Nigeria. Chief among the factors are incompetent of electoral commission which serves as an umpire in the electoral process, do-or-die syndrome of the political parties to capture political power by all means, widespread procedural irregularities, numerous incidence of violence, intimidation of the electorate, stuffing of the electoral box, poverty on the part of the electorate, etc. The outcomes of many elections have been so fiercely contested that the survival of the country and democracy has been jeopardized. This sad history of election fraud has serious implications for Nigeria's political future because the phenomenon rather than declining, keeps growing and becoming more sophisticated with every succeeding elections ${ }^{42}$

\section{Aside from the challenges set out above, other challenges include:}

(a) Delay in Electoral Justice

The judiciary by virtue of S.6 of the CFRN has the power to settle and determine disputes arising from the electoral process. However, the judiciary will not interfere in the internal affairs of the parties, though the judiciary will not allow the violations of the principles of rule of law and fair hearing by parties. Hence, under Sections 66, 107, 137 and 182 of the 1999 Constitution as amended the judiciary generally has the power to intervene in pre-election conflicts. For example, the courts generally have the jurisdiction to determine whether a candidate is qualified for an election and the validity of the nomination of a candidate for an election.

S.285 CFRN as amended however specifically spelt out the courts that have jurisdiction on post electoral matters ${ }^{43}$, particularly as regards whether or not a candidate had validly won an election, or whether an election was validly contested. In such a situation, S. 143 of the electoral Act allows the person elected to remain in office pending appeal once the notice of appeal has been filed within the time limit. S.142 of the Electoral Act provides for accelerated hearing of election petitions, and S.285 (5)-(7) provides for time limit within which to file election petition.

Delay in resolving electoral disputes is a significant challenge to election petitions in Nigeria. For example, the election petition of General Mohammed Buhari against the re-election of Chief Olusegun Obasanjo took over two years to be concluded. ${ }^{44}$ It also took about three years for the court to decide the case of Peter Obi v Chris Ngige. ${ }^{45}$ Ike Ekweremadu, posited that "protracted electoral cases in our courts/election tribunals which extend deep into the term of office of elected officers, is a serious embarrassment to our electoral process." Electoral grievances should be addressed quickly, promptly and with dispatch.

Efforts to cure the delay in the administration of Justice by the introduction of time limit within which to file an electoral petition have proved significant. Its strict application has also resulted in the dispensation of technical justice. It is likely to be an infringement of the right to fair hearing as guaranteed under the 1999 Constitution.

\footnotetext{
${ }^{39}$ A. Jega an O. Ibeanu, (2007), "Elections and the Future of Democracy in Nigeria” Nigeria Political Science Association, Nigeria

${ }^{40}$ Edoh, H. ((2004). "Corruption: Political Parties and the Electoral Process in Nigeria," in Jibo, M. and Simbine, A.T. (eds.), Contemporary Issues in Nigerian Politics, Ibadan: JODAD Publication

${ }^{41}$ Elaigwu, J.I. (2007). Nigeria: The Current State of the Federation: Some Basic Challenges, Paper presented at International Conference on Federalism in Honour of Professor Ronald Watts, Organized by the Institute of Intergovernmental Relations, Queens University, Kingston, Canada, October 18-21, 2007.

${ }^{42}$ A. Awopeju, "Election Rigging And The Problems Of Electoral Act In Nigeria Afro Asian Journal of Social Sciences Volume 2, No. 2.4 Quarter IV 2011 ISSN 2229 - 5313

43 "The Supreme Court is now the final appellate court on Gubernatorial elections by virtue of S. 233 (2) (e) (iv) of the 1999 Constitution as amended, while by S. 239 (1) (a) the Court of Appeal is the Court with original jurisdiction to hear matters arising from Presidential elections. States also have responsibility to create electoral tribunal to deal with Local Government elections by virtue of S. 7 (1) of the 1999 Constitution " Fagboun

${ }^{44}$ Buhari v Obasanjo (2003) 11 S.C. 74.

${ }^{45}$ (2006) 14 NWLR (Pt. 999) 1
} 
It is our suggested opinion that elections to the Office of the President and Governors should be held at least 9 months to the expiration of their tenure and no one should be sworn in before the conclusion of his case.

\section{(b) God fatherism and democratic process}

Few influential individuals have taken absolute control of the political parties. These individuals are not bound together by any political or economic ideology. They do not have a uniform stance on burning issues like derivation, resource control, abortion, transsexual, free education, etc., rather they have a common aspiration to control and manipulate party structures, and select cronies to hold political offices. These powerful individuals are often more popular than the parties manifestoes!

\section{(c) Conflicting Election Tribunal Decisions}

Conflicting decisions of courts in electoral matters is another sore-point. It weakens the confidence of all the stakeholders, inclusive of the politicians and the electorates in the integrity of the judiciary. For example, concerning the validity of the June 12, 1993 elections, Ikpene CJ of the High Court of the Federal Capital Territory, Abuja had restrained the National Electoral Commission from conducting the presidential elections. However, the Commission went ahead to conduct the elections relying on the provisions of Section 19(1) of the Presidential Election Decree. On June 21, 1993 the High Court of the FCT voided the election ${ }^{46}$. Saleh J held that the election was illegal on the ground that it was held contrary to a court order prohibiting same and all matters in relation to the election be suspended until further notice. On the other hand, on June 17, 1993, Olugbani J of the High Court of Lagos State, had ordered the Commission to announce the result of the elections $^{47}$. On June 18, 1993, Aguda J of the High Court of Ondo State ordered the Commission to declare the results of the elections within 48 hours, ${ }^{48}$ the same day Ayorinde of the High Court of Oyo State had ruled that the Commission should release the outstanding results. ${ }^{49}$

The orders and counter orders of the courts turned the judiciary into a laughing stock, an otherwise respected and conservative body was turned into theatre of comedy. Nigerians agonisingly watched the soap opera while it lasted.

\section{(d) Non-Prosecution of Election Related Offences}

Non-prosecution of electoral offenders has encouraged and nurtured a culture of impunity across political parties. In all, the general elections that have been conducted in the country, there has always been allegations of perpetration of violence either by party thugs, at times in the presence of military and police personnel or by the military and police personnel themselves in favour of their favoured political party. The then Interim National Publicity Secretary of the Action Congress of Nigeria (ACN), Alhaji Lai Mohammed, stressed that:

Nation's need was actually the political will to deal with electoral offenders in the interest of all and sundry. We have heard that in the past. But will political will to persecute them be there? It is one thing to make laws; it is another thing to ensure compliance. ${ }^{50}$

\section{(e) Pervasive Grand Corruption}

Corruption pervades the Nigerian political space, it is widespread. Corruption flows ceaselessly in Nigeria. The effect of corrupt practices amount to a perpetual torment of the citizenry, just recently the US opined that the Nigerian government has been unable to deal with the Boko Haram insurgency because of corruption $^{51}$. The effect of corruption is multi-dimensional ${ }^{52}$, investing the political and electoral process. For democracy to thrive in Nigeria, the government must address and curtail this monster. Corruption undermines democracy, it kills the poor, and it undermines the justice system and the electoral system. It erodes confidence in government. Mismanagement of resources, wastages, luxurious living are common vices among the political elites, irrespective of party affiliate. It is our collective burden to fight corruption. Corrupt politicians are averse to a credible electoral process. A significant number are corrupt. The anti-corruption agencies are slowly grinding to a halt. In the face of serious allegations of financial recklessness against some top government

\footnotetext{
${ }^{46}$ Guardian Newspapers Tuesday, June 23, 1993 p.1

${ }^{47}$ New Nigerian Newspapers Thursday June 241993 p.1

${ }^{48}$ Daily Sketch Newspapers, Saturday June 19, 1993

${ }^{49}$ Ibid at p.3

${ }^{50}$ Nigerian Compass, Thursday, September, 2, 2010.

${ }^{51}$ Sarah Sewall, the US Under Secretary of State for Civilian Security, Democracy and Human Rights said this while appearing before a hearing of the US House Foreign Affairs Committee on Wednesday 14 May, 2014. Available at: http://www.punchng.com Accessed on 15 May, 2014

${ }^{52}$ For further discussion on this see Bello and Odusote "The Matrix of Bad Governance: Corruption And Insecurity In Nigeria" Being paper presented at the Nigerain Law Teachers Conference, held at the University of Ilorin, 2013 pages 3-23
} 
functionaries, the anti-graft agencies have been unable to act. On the face of it, and by reason of admissions, some of the top government functionaries are culpable, yet the police and the anti-graft agencies are not acting.

\section{(f) Electoral Disenfranchisements ${ }^{53}$}

S. 12 (1) provides that a person shall be qualified to be registered as a voter if such a person: (a) is a citizen of Nigeria; (b) has attained the age of eighteen years; (c) is ordinarily resident, works in, originates from the Local Government/Area Council or Ward covered by the registration centre; (d) presents himself to the registration officers of the Commission for registration as a voter; and (e) is not subject to any legal incapacity to vote under any law, rule or regulations in force in Nigeria. In addition, Sections 77(2), 117(2), 132(5), and 178 (5) of the 1999 Constitution granted franchise to adult citizens irrespective of whether the citizen was acquired by birth, registration or naturalization.

The case of Nigerians residing outside the country should be considered by the National Assembly. These set of Nigerians should be allowed to vote at the Nigerian Embassy of their respective choice of residents. It is unfair to keep disenfranchising several million of Nigerians just because they reside outside the country. It has also been suggested by Fagboun that prisoners and awaiting trial inmates be afforded the opportunity to vote, he argued:

The fact that a person has been sentenced to prison or awaiting trial should not mean that the person has ceased to be a citizen. The situation is more worrisome for a country like Nigeria where substantial number of people are awaiting-trial detainees. A number of jurisdictions now view it as invidious to disenfranchise on grounds of gender, race, class or status. The denial of the right to vote to any segment of the population has serious implication in a democratic setting. Aside of the fact that it affects the outcome of an election, it also devalues citizenship. Prior to 2001, "legal incapacity" under the electoral laws of Nigeria includes the imposition of sentence of death, or in respect of an offence involving dishonesty, of imprisonment for a term exceeding six months or such other punishment as may lawfully be substituted therefore, and the voter has not at the date of the election suffered the punishment or received a free pardon. Beginning from the Electoral Act 2001, the situation changed. "Legal incapacity" was redefined to mean " $a$ person disqualified under the Constitution or the Electoral Act, or any other Law, Rules and Regulations from registering as a voter or from contesting elections. ${ }^{54}$

We agree no less with the erudite scholar that prisoners, particularly those that have not been condemned to death, and awaiting trial inmates should not be disenfranchised. As is it amounts to double jeopardy for the awaiting trial inmates. This set of Nigerian should be made to feel part of the system by way of encouragement and reorientation. This is the practice in other part of the world.

(i) INEC lacks financial autonomy.

INEC relies on subvention from the federal government while the State Independent Electoral Commissions relies on subvention from the state governments. The chairmen and members of the electoral bodies were appointed by the president and governors subject to the approval of the senate and Houses of Assembly respectively. They lack financial autonomy. Allocations are made to INEC by the federal government, while the state governments made allocations to the state INECs from the states' allocations. These provisions do not ensure the independence of these bodies. He who pays the piper dictates the tune. These bodies are potentially exposed to the benevolence, generosity, and by implication manipulations by the president and the governors. There is an urgent need to amend the relevant sections of the constitution to ensure the independence of the umpire, INEC. We agree with Osipitan that, "the financial autonomy of INEC is best guaranteed if the budgetary allocation is charged to the Consolidated Fund." ${ }^{, 55}$

\section{Conclusion}

In sum, from the discourse above, it is incontrovertible that there is a huge disconnect between the political elite and the people by reason of the fact that the Nigerian electoral system has been far from being credible. Voters have no form of control or influence over their political representatives. It is also sad to note the disconnect between the Nigerian political leadership and the citizenry, there is so much apathy to the needs,

\footnotetext{
${ }^{53}$ Lunatics, people of unsound mind, prisoners sentenced to death, and minors are generally excluded from voting.

${ }^{54}$ Fagbohun, "Nigeria's Democracy and the Crisis of Political Instability: An Audit of the Electoral System" Being text of paper delivered at the June 12 Anniversary Lecture organized by the Political and Legislative Powers Bureau of Lagos State Government in conjunction with the June 12 Coalition on 12th June 2013 on the theme Electoral System, the Bane of Political Instability in Nigeria

${ }^{55}$ Prof. T. Osipitan, SAN “The Search for Credible Elections in Nigeria: Electoral Laws and Functional Education” being a text of the paper presented at the $15^{\text {th }}$ Annual Lecture, award of honours and postgraduate scholarships of Stephen Oluwole Awokoya Foundation for Science Education at the AGIP Recital Hall, Muson Centre, Onikan, Lagos on 16 March, 2010.
} 
Nigerian Democracy and Electoral Process since Amalgamation: Lessons from a Turbulent Past*.

common good and the general welfare of the citizenry. Corruption, grand corruption, kidnapping, untimely deaths, political thuggery and banditry, pervasive insecurity across the country have now become common place.

\section{i. Reformation of political culture through civic education and citizen participation}

Nigerian populace is generally docile; there is prevalence of voter's apathy. In most elections, voters' turnout is generally low. This gives ample opportunity for the election riggers to have a field day. Voters should be educated on the need to exercise their right to vote through voters initiatives. It has been suggested that voters' education initiates are a proven way of minimising fraud, violence, and ballot stuffing ${ }^{56}$

ii. Adequate and timely preparation for elections

iii. Political parties should be registered strictly on clearly defined ideology

Political parties should be made to clearly state their political persuasions and their manifestoes must be presented and audited before registration. It must also be widely published on the parties' website and in at least two national newspapers. This is important because as it is, electorates cannot distinguished between the PDP, and the APC on issues such as payment of fees in tertiary institutions, insecurity (whether or not amnesty should be granted to militants), privatisation, job security, judicial independence, and electoral independence. Issues are not the distinguishing factor but religion and resort to verbal abuses and ethnicity.

\section{v. Electoral Act should be amended to allow Independent candidacy}

Independent candidate is an individual that is not affiliated or belong to any political party. Presently by virtue of S. 7(4), S. 65 (2) (b), S.106 (d) S. 131 (c) S.177(c) and S. 221 CFRN only political parties can canvass for votes for any candidates. S. 221 states:

"No association, other than a political party, shall canvass for votes for any candidate at any election or contribute to the funds of any political party or to the election expenses of any candidate at an election"

These provisions prohibit independent candidacy in elections. It is necessary, particularly, in this clime, where some cabals have hijacked political parties, independent candidate assumes personal responsibility to the people. He will not be affiliated to any godfather, neither will he be liable to make returns to a godfather.

\section{vi. Establishment of Electoral Offences Commission}

The Electoral Act 2011 prescribes various punishments for diverse offences under the Act. S. 117 (1) prescribes offences in relation to registration and prescribes punishment. Section 118 states the offences in relation to nomination and prescribes punishment for its violation, S.119 states the offences of disorderly behaviour and prescribes punishment for same. Other offences include, ballot stuffing, impersonation, bribery and conspiracy, and threatening ${ }^{57}$. It is worrying to note that despite the criminalization of the above acts, they are still being violated with impunity because there are no real consequences for their violations. It is more disturbing to note that only very few individuals have been convicted for electoral offences, despite its rampancy. We are not aware of anyone convicted of politically motivated murder. It is our opinion that a special Electoral Offences Commission be established to prosecute electoral offences. This was recommended by the Electoral Reform Committee (Uwais Committee), the Electoral Offences Commission should be established and adequately funded, staffed and equipped for the purposes of effective apprehension, prosecution and trial of electoral offenders. INEC should be left with the primary duty of conducing elections, registration of political parties, conducting civic education, promoting knowledge of sound democratic election process etc. ${ }^{58}$

vii The Independent National Electoral Commission (INEC) should be empowered to monitor campaign funding and ensure greater transparency and accountability on campaign spending. There should be a clear legislation on how political parties should be funded ${ }^{59}$. S. 91 of the Electoral Act 2011, provides for limitation on election expenses but there is no effective machinery to monitor compliance. S. 90 (9) provides for instance that no individual or other entity donations to a political party should be more than one million naira. This is being violated (despite the punishment prescribes in S. 90 (10) without any consequences ${ }^{60}$. There should also be consequential punishments for violations. This paper agrees with Bello and Odusote that:

The foundation for good governance is laid when credible elections are held and when there is in existence a credible electoral system that will attract the best candidates to present themselves for election. At the moment, there is growing apathy and lack of confidence in the electoral process. Hence, we propose that the appointment, tenure,

\footnotetext{
${ }^{56} \mathrm{IiG}$, "Campaign finance distorts Nigerian elections" available at http://www.iig.ox.ac.uk Accessed on 12 February, 2014

${ }^{57}$ Sections 117-131 Electoral Act 2010

${ }^{58}$ S. 2 Electoral Act, 2010

${ }^{59} \mathrm{IiG}$, "Campaign finance distorts Nigerian elections" available at http://www.iig.ox.ac.uk

${ }^{60}$ Other provisions being violated include S.92 (2) and (3) to the effect that election expenses incurred by a political party shall be determined by INEC in consultation with the political parties. It is also a requirement of the Electoral Law that election expenses be
} submitted to INEC by the political parties in a separate audited return within six months after an election. 
composition of the Independent National Electoral Commission of Nigeria (INEC) be made independent. INEC is a very critical institution in the pursuit of good governance in Nigeria. It should be strengthened in terms of independence and capacity to midwife a credible election. Its members should be appointed by a non-partisan body or through a collective process jointly agreed to by all the registered political parties. Also, the process of registration, voting and counting of electoral votes should be technology driven and biometric based. Finally, there must be fervent prosecution of perpetuators of electoral and political violence. As discussed above, there is already in existence an avalanche of legislative framework that can drive the process. Culture of impunity must stop. In addition we recommend budget autonomy for INEC, its funding must be made available from the Federation Account. ${ }^{61}$

viii. The Federal Government should ensure INEC compiles, maintains and update the Voters' register on a continuous basis in accordance with Section 9(1) of the Electoral Act 2010. Early preparation and continuous update of the Voters register will prevent the chaotic polling stations of the 2011 elections.

We want to conclude by asserting that Nigerian democracy still has a long road to cover, and there are many potholes. We need to state emphatically that until political and electoral distortions highlighted above are removed, and the suggested recommendations giving effect, all efforts to deepen democracy and the clamour for good governance in Nigeria will amount to a chimera.

\footnotetext{
${ }^{61}$ Bello and Odusote, "The Matrix of Bad Governance: Corruption And Insecurity In Nigeria" Being paper presented at the Nigerain Law Teachers Conference, held at the University of Ilorin, 2013. P.36 